
\title{
CIÊNCIANATURA
}

\section{Analysis of water quality in the watershed Brazilian semiarid}

\section{Viviane Farias Silva*, Dihego Souza Pessoa, Thalis Leandro Bezerra Lima, Ana Maria Ferreira Cosme,} e Vera Lucia Antunes Lima

Universidade Federal de Campina Grande, PB, Brasil

\begin{abstract}
Water is a renewable natural resource, important for maintenance of life on the entire planet. Even with this significance is a feature that has been degraded and reduced the quality to use. In the Brazilian semi-arid region water scarcity by influencing the quality of life of the population, directly affecting the socio-economic and development means. In this context, the present research was conducted aiming to evaluate the water quality in the watershed Brazilian semiarid. The survey was conducted in three watersheds (Capibaribe river, Ipojuca river and Igarassu river) in the State of Pernambuco, Brazil. Water Quality Index (WQI) and Biochemical Oxygen Demand (BOD) annual averages of the year 2006 to 2015. In Capibaribe river watershed the largest concentrations of BOD occurred in 213, 2014 and 2015, with average was $4.95 \mathrm{mg} / \mathrm{L}$. By increasing the BOD value there is a reduction of WQI. The Igarassu river, it was verified that from 2006 to 2014 the hydrographic basin has water quality classified as good. The BOD in the waters of the Ipojuca river has little influence on the water quality index.There is a degradation on the quality of water of basins due mainly to anthropic pollution.
\end{abstract}

Keyword: Water scarcity; Water degradation; Anthropic pollution 


\section{Introduction}

The questions about the quality of the water distributed and consumed by the supply systems and forms of personal consumption were better extended thanks to enactment of the Federal Law No. 9,433/1997, establishing the national water resources Policy, Silva et al. (2009). In the last decade, the amount of studies and research developed with this purpose to investigate problems in the quality of water used for public supply has increased significantly considering the amount of water used in its many forms, from watering, recreation, irrigation and industrial production processes (ROCHA et al., 2010).

Identification of polluting sources of dams and other water bodies is essential for the control of water quality. The increase of agricultural and industrial activities in addition to the daily domestic activity increases consecutively the residual effluents of such activities and the destination of these effluents is not always correct or even noticed (FRANCO and HERNANDEZ, 2009). Thus, the increase in human consumption has not also accompanied an increase in monitoring of water that is offered to the population, especially since the various forms of pollution reaching water bodies in various ways, whether by air, solid organisms etc. The residual effluent itself was served by the water, and it became the contaminant agent in the water bodies of water quality that will be used in the future, (MELO NETO et al., 2008).

Thus, it is essential to monitor the water quality with effective monitoring of physical and chemical parameters, and in the case of water bodies such as dams, it is also important to offer materials and partnerships between public bodies for better management of resources related to water that are effective for the consumer population, mainly (FIGUEIRÊDO, 2008). The study of hydrographic basins in urban and rural areas must be in full correlation because water quality is the result and balance of the extraction and exploration of the environment and natural resources in general and the ability of the environment to be explored could regenerate air and not be used as a source of waste disposal, cooperating in this direction with the sustainability of the environment (SILVA et al., 2006).

The disordered and unplanned increase of urban areas which does not respect the conditions of the drainage area and consideration of the fate of residues in the neighborhood, use of toxic agricultural frontier areas and the high impact of livestock activities aggravates the effects of pollution of natural resources. Araújo (2000), the changes, especially the conditions water characteristics are inherent with the use of the soil and your occupation around your owned drainage basin. One of the major effects that can increase or decrease the quality of the water in this case include the presence or absence of vegetation and which human activities are carried out.

The Brazilian semiarid region, characteristic for the few and scattered rains in your territory, corresponding to much of the Northeast, suffers from pollution and contamination of water bodies that make up the landscape and your reality. In this region, where water takes a special condition for human consumption seen the great difficulty of access to this natural resource, high evapotranspiration characteristic of the region, promotes a condition the susceptibility of water unfit for human consumption, the main one being the high salinity of the water that concentrate the salts present in the water body, often being found in brackish or saline already ratings (SILVA et al., 2004).

As the quality of the water represents the State of health of people that use it, the reality and the welfare population is a result of how the health of water consumed. To succeed with the implementation of a quality water for safe use in all their uses, it is necessary to perform the characterization of water in their physical and chemical parameters, as already provided for, but also with the microbiological analysis, and in this sense the resolution CONAMA 357/05 provides parameters that are qualitatively to report water quality in study (MINISTRY OF THE ENVIRONMENT, 2017).

In this context, the present research was conducted aiming to evaluate the water quality in the watershed Brazilian semiarid.

\section{Material and Methods}

The survey was conducted in three watersheds in the State of Pernambuco. According to Agency Pernambucana de water and climate (APWC, 2017) the Capibaribe river (Figure 1A), It is situated in the State of Pernambuco in the following geographical coordinates: $07^{\circ} 41^{\prime} 20^{\prime}$ e $08^{\circ} 19^{\prime} 30^{\prime}$ 'South latitude, $34^{\circ} 51^{\prime} 00^{\prime \prime}$ and $36^{\circ} 41^{\prime} 58^{\prime}$ " West longitude. The Ipojuca river (PE) is located (Figure 1B), between South latitudes $08^{\circ} 09^{\prime} 50^{\prime \prime}$ and $08^{\circ} 40^{\prime} 20^{\prime \prime}, 34^{\circ} 57^{\prime} 52^{\prime \prime}$ and $37^{\circ} 02^{\prime} 48^{\prime \prime}$ West. The water watershed of the Igarassu river (PE) South latitudes $07^{\circ} 81^{\prime} 81^{\prime \prime}$ and 34 $86^{\prime} 30^{\prime \prime}$ West longitude, IBAMA (2009), Figure 1C.

Second report of the state planning and research agency of Pernambuco (CONDEPE-FIDEM, 2009) the State does not rivers of great extension, no significant volume of water, except for the São Francisco River, which serves as a natural boundary between the states of Pernambuco and Bahia. The relief in the State of Pernambuco is divided physically, North to South, through the Borborema upland. Therefore, the rivers of the eastern part have an eastbound flow, flowing into the Atlantic Ocean.

The surface water resources of the Northern Coast of Pernambuco are included in the Group of Small Littoral watershed (GL1-CONDEPE, 1980). The main rivers rise upstream from the coastal plain, flowing into the Atlantic Ocean or into the Santa Cruz Canal. With an area of $143,412 \mathrm{~km}$ corresponding to $0.14 \%$ of the total area of the state, and with the perimeter of $10.2 \mathrm{~km}$, the Igarassu watershed has almost all its lands in the municipalities of Igarassu (81.7\%), and Abreu and Lima (16.1\%) and occupy, respectively, $39.2 \%$ and $16.8 \%$ of the surface of these municipalities. 
Figure 1 - Location of hydrographic basin of the Capibaribe (A), Ipojuca (B) e Igarassu (C), analyzed

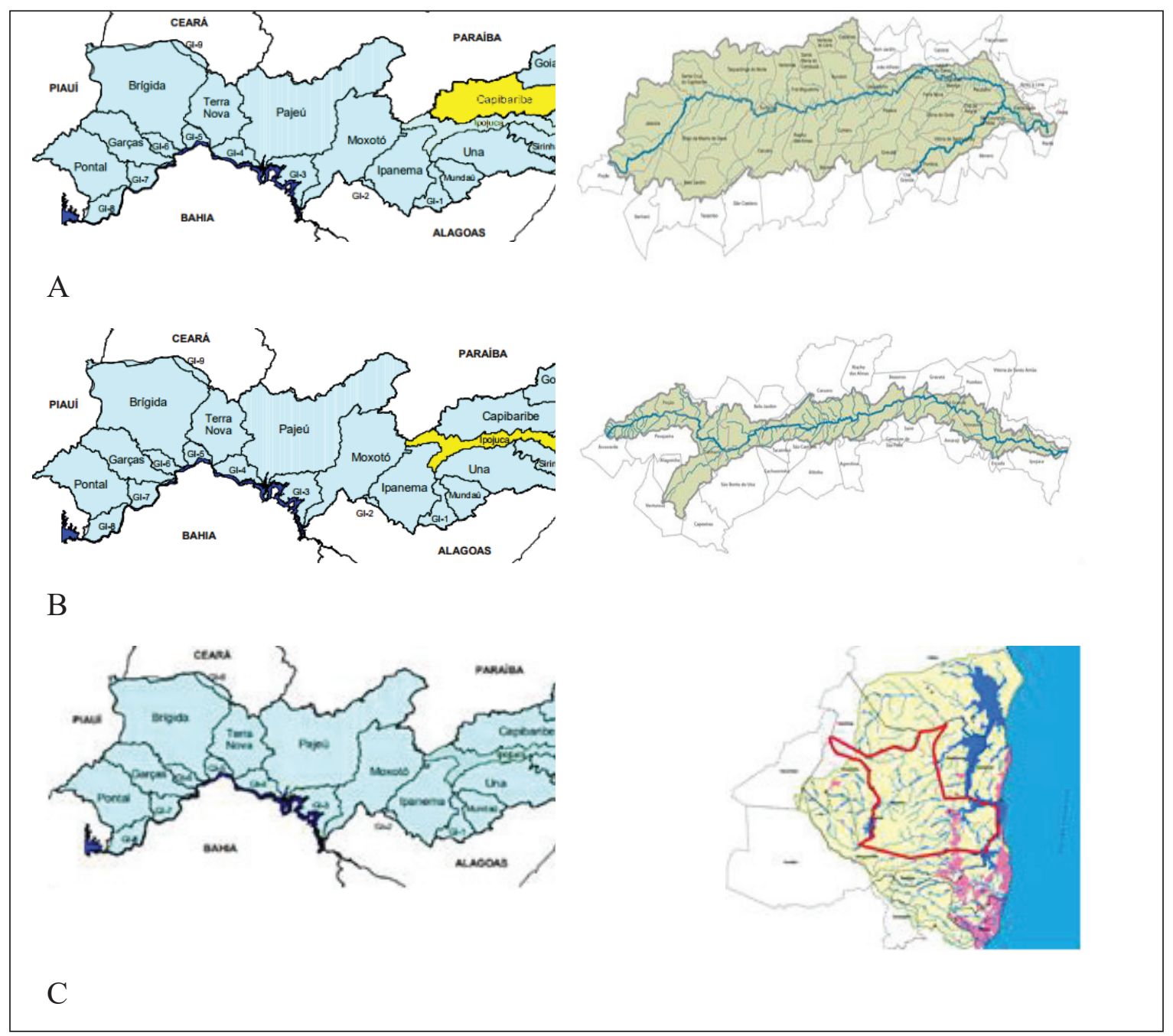

Source: SRHE-PE(2017); IBAMA (2009).

The data were obtained in the in the information database of the Sustainable Development Indicators - SDI (2017), Water Quality Index (WQI) and Biochemical Oxygen Demand (BOD) annual averages of the year 2006 to 2015 the following catchment areas of Pernambuco are: Capibaribe River; Igarassu River and River Ipojuca. The annual precipitation of the State of Pernambuco referring to the years from 2006 to 2015, were obtained from the Pernambucana Water and Climate Agency.

The averages, the variation of the quality of the water for public supply and its classification in the different periods per the national council of the environment 357/2005. The descriptive analysis, time series analysis, the estimated regression model and parameters is the least squares Ordinary (OLQ) was performed with Gretl 3 software (GRETL, 2013).

The water quality assessment according to the reference values of the National Water Agency (NWA, 2017), according to Table 1.

Table 1 - Water quality index ranges for water quality assessment of river basin

\begin{tabular}{ll}
\hline WQI & Water quality assessment \\
\hline $80-100$ & Great \\
$52-79$ & Good \\
$37-51$ & Reasonable \\
$20-36$ & Bad \\
$0-19$ & Very Bad \\
\hline
\end{tabular}

Source: NWA, 2017. 


\section{Results and discussion}

Analyzing the averages, it can be seen in Table 2 that the Igarassu River has the highest WQI average (57,67), but in BOD maximum is the highest rate in the Ipojuca river basin $(74,00)$ in 10 years. By analyzing the water quality through the means, can affirm that it is in the range of good water quality. The minimum of WQI with 38.00 and for BOD in $1.60 \mathrm{mg} / \mathrm{L} \mathrm{for} \mathrm{Iga-}$ rassu. The standard deviation ranged from 2.26 to 10.65 . The coefficient of variation ranged from 13.88 to $20.50 \%$ for WQI.

Table 2 - Descriptive analysis of water quality index, biochemical oxygen demand and precipitation

\begin{tabular}{l|l|l|l|l|l|l}
\hline & \multicolumn{5}{|c}{ Water Quality Index } \\
\hline River & Mean & Minimum & Maximum & $\begin{array}{l}\text { S t a n d a r d } \\
\text { Deviation }\end{array}$ & $\begin{array}{l}\text { Coefficient of variation } \\
(\%)\end{array}$ \\
\hline Capibaribe & 54,5 & 43,00 & 71,00 & 8,32 & 15,2 \\
\hline Igarassu & 57,67 & 38,00 & 66,80 & 8,00 & 13,88 \\
\hline Ipojuca & 51,83 & 41,30 & 74,00 & 10,65 & 20,5 \\
\hline River & \multicolumn{5}{|c|}{ Biochemical Oxygen Demand (mg/L) } \\
\hline Capibaribe & 7,21 & 4,20 & 14,10 & 3,55 & 49,03 \\
\hline Igarassu & 4,85 & 1,60 & 8,60 & 2,26 & 46,76 \\
\hline Ipojuca & 9,86 & 4,10 & 24,70 & 6,61 & 67,08 \\
\hline & 43,28 & 21,40 & 51,20 & 8,63 & 19,94 \\
\hline
\end{tabular}

The precipitation in the analyzed 10 years had a mean of $43.28 \mathrm{~mm}$, with a minimum value of 21.40 mm and a maximum of $51.20 \mathrm{~mm}$, with a coefficient of variation of 19.94\% (Table 2). The year 2008, 2013, 2014 and 2015 are classified as water of reasonable quality. The other years had values above 51 being considered of good water conditions (Figure 2A).

By increasing the BOD value there is a reduction of WQI, so when the BOD reached a higher index the WQI had an abrupt drop, thus decreasing the quality of the water. When carrying out the ordinary least squares analysis, the following equation was obtained (WQI $=67.49-1.8 * \mathrm{BOD}$ ), it was contacted that by increasing by one unit the BOD value there is a decrease of $1.8 \mathrm{WQI}$, in this way the BOD being zero the WQI would be 67.49 , being a good quality water, however increasing the BOD value, the index is reduced and consequently the quality of the water, Figure $2 \mathrm{~A}$ and $\mathrm{B}$. 
Figure 2 - (A)Temporal series of water quality index (WQI) and Biochemical Oxygen Demand (BOD); (B) Temporal series of water quality index (WQI) effective and adjusted versus Biochemical Oxygen Demand (BOD); (C) Temporal series of water quality index (WQI) effective and adjusted versus precipitation of the Capibaribe river
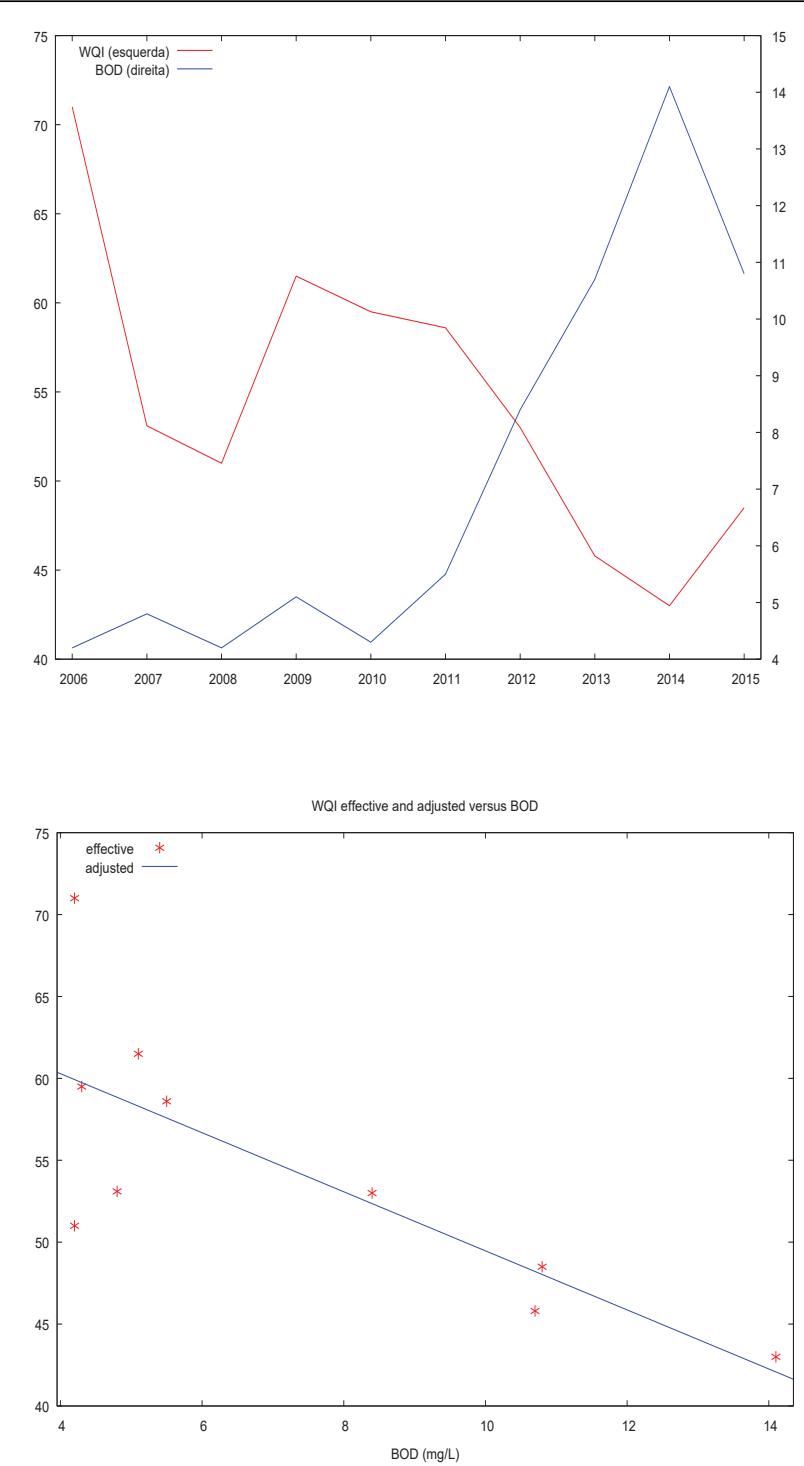

$\mathrm{C}$

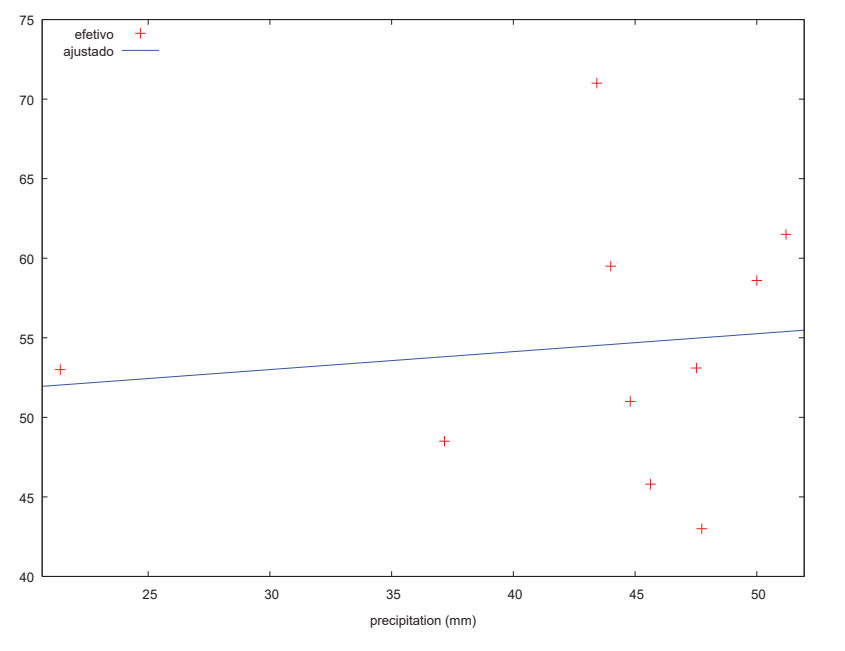


In Figure 2A, Capibaribe river watershed the largest concentrations of BOD occurred in 213, 2014 and 2015, with 50\% of the years the BOD was below the level permitted for human consumption, namely, $5 \mathrm{mg} / \mathrm{L}$, as established by CONAMA (2005). With highest elevation in the year 2014, with about of $14.1 \mathrm{mg} / \mathrm{L}$ and is inappropriate for drinking. Effective and adjusted WQI with the obtained formula versus BOD, Figure 2B, it is verified that increasing BOD reduces WQI and when WQI increases, there is a reduction of BOD.

The estimated regression equation $\left(\mathrm{WQI}=49.62+0.11^{*}\right.$ Precipitation) in relation to WQI and precipitation, Figure $2 \mathrm{C}$, so when precipitation rises in 1 unit or $1 \mathrm{~mm}$ has a 0.11 increase in WQI. Thus the higher the precipitation index the higher the WQI and the better the water quality.

According to the resolution the national council of the environment 357/2005 (BRAZIL, 2005), to the framing of the water bodies of fresh water in Classes 1, 2 and 3 the BOD values should not exceed $3 \mathrm{mg} / \mathrm{L}, 5 \mathrm{mg} / \mathrm{L}$ and $10 \mathrm{mg} / \mathrm{L}$, respectively. In no time the Capibaribe River basin has been classified as Class 1, 50\% of the years are considered of class 2 water, while in other years were classified as class 3 .

Teixeira et al. (2013) researching the quality of the water in the basin of the rio Capibaribe, observed that there is decrease of water quality in the course of your route mainly by anthropogenic degradation occasioned.

Bione et al. (2013) verified that approximately $84 \%$ of the municipalities launch without any previous treatment your sewers in the Capibaribe river or its tributaries, although there are several treatment plants, the majority is not in operation.

The Igarassu river, it was verified that from 2006 to 2014 the hydrographic basin has water quality classified as good, while in 2015 there is a decrease in the value of WQI, reducing the water quality, considered reasonable. The biochemical oxygen demand high levels in the year $2014(8.6 \mathrm{mg} / \mathrm{L})$, Figure $3 \mathrm{~A}$.

Figure 3 - (A)Temporal series of water quality index (WQI) and Biochemical Oxygen Demand (BOD); (B) Temporal series of water quality index (WQI) effective and adjusted versus Biochemical Oxygen Demand (BOD); (C) Temporal series of water quality index (WQI) effective and adjusted versus precipitation of the Igarassu river

A

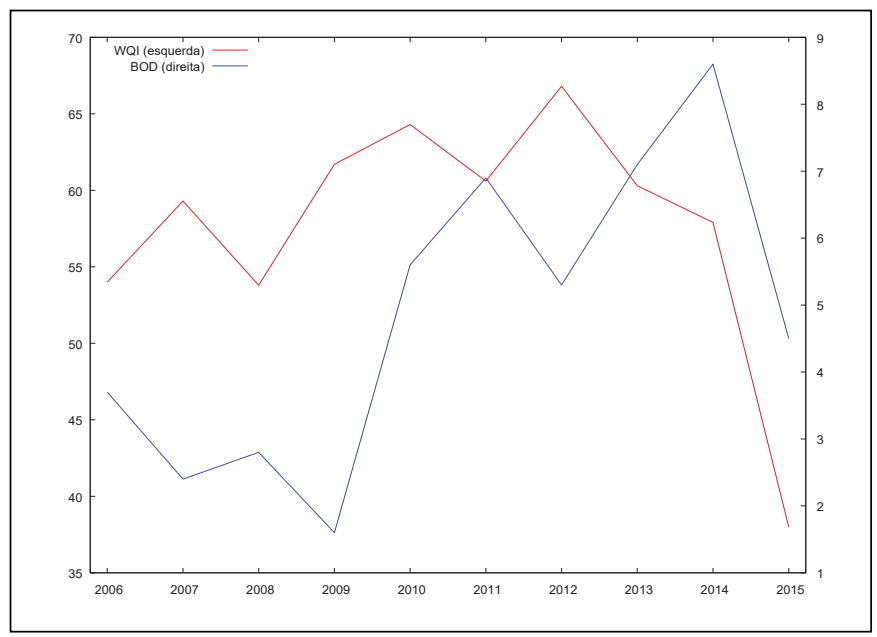

B

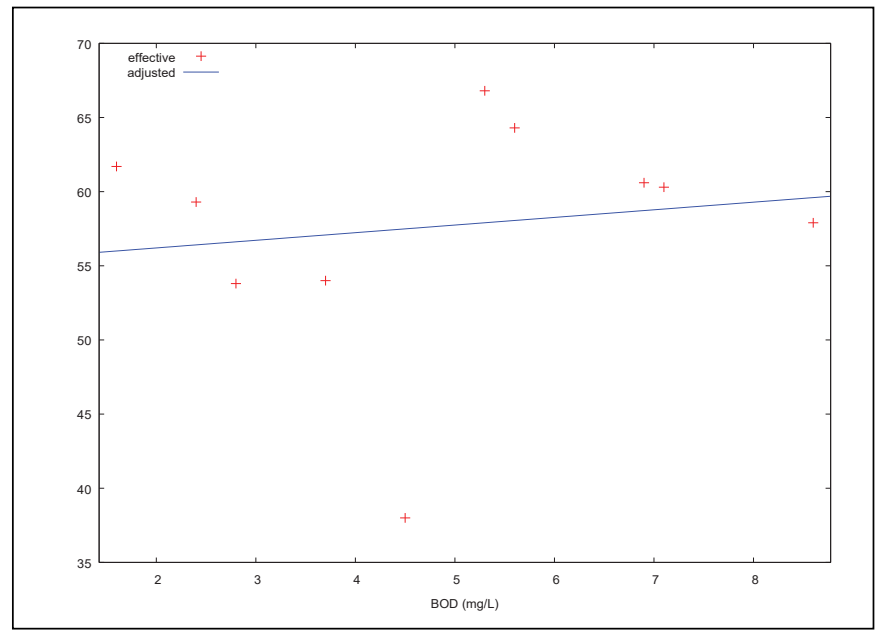

$\mathrm{C}$

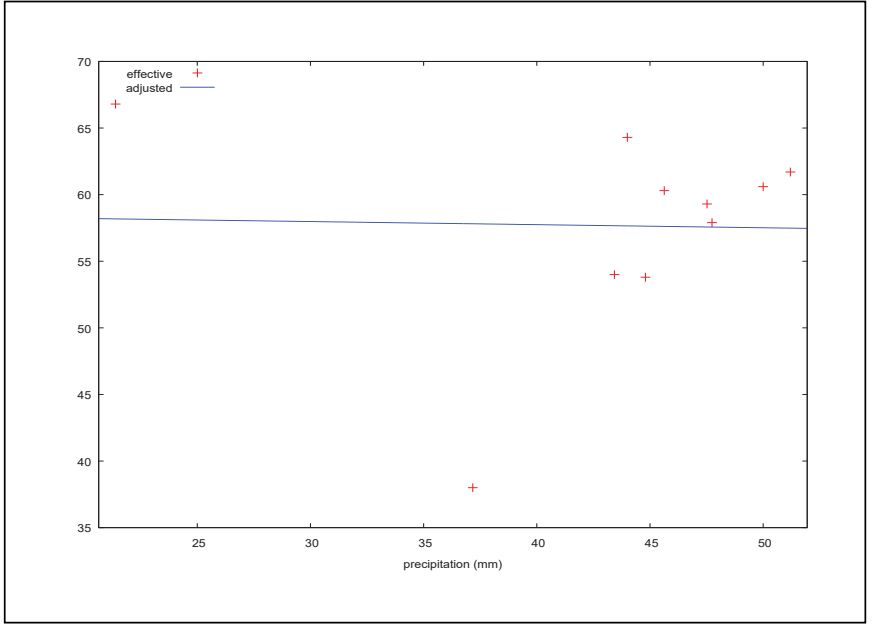


In Figure 3B, it is observed that the regression equation obtained (WQI $=55.17+0.51 * \mathrm{BOD})$ by increasing $1 \mathrm{mg} / \mathrm{L}$ of BOD will be added 0.51 in the WQI. Em relação a precipitação versus o WQI, conforme a equação de regressão (WQI=58. $68-0.023 * \mathrm{BOD})$ it is observed that a rainfall of $1 \mathrm{~mm}$ raises the WQI, increasing water quality.

In times of higher rainfall indices it is observed that there is an increase in water quality, Figure $3 \mathrm{C}$, even if not significantly, due to the environmental impacts caused by the discharge of effluents. According to Fiden (1987) on the river Igarassu domestic and industrial sewage are released that directly affect the quality of water and over time the amount of population is growing and the inadequate disposal of waste into water bodies. Justifying how the increased level of BOD in the course of time in the water being inversely proportional to the quality of water, to raise the level of BOD reduces water quality. IBAMA (2009) report that the monitoring carried out in the river water quality Igarassu was committed to standards outside the limit, as well as levels of fecal coliforms and phosphorus.

Costa and Ferreira (2015), when analyzing the water quality index in the Mineira portion of the Paranaíba River Basin, observed that the water quality classification was predominant as a mean, that is, $50<\mathrm{IQA} \leq 70$.

The water quality index in the Ipojuca river basin, $60 \%$ of the analyzed years are classified in the water quality classification as reasonable, noting that only $40 \%$ of the WQI were considered of good quality. With the highest index in the year 2006 and the lowest in the year 2011 and 2012, in Figure 4.

The Biochemical Oxygen Demand over the years had an average of $9.86 \mathrm{mg} / \mathrm{L}$, with a lower index in $2006 \mathrm{with} 4.1 \mathrm{mg} /$ $\mathrm{L}$ and high levels in $2014(24.7 \mathrm{mg} / \mathrm{L})$. It is observed that the WQI is high in the year 2006 and decreases abruptly until the year 2008, continuing to reduce however slowly, from 2012 to 2014 there is an increase in water quality, Figure 4A.

Figure 4 - (A)Temporal - series of water quality index (WQI) and Biochemical Oxygen Demand (BOD); (B) Temporal series of water quality index (WQI) effective and adjusted versus Biochemical Oxygen Demand (BOD); (C) Temporal series of water quality index (WQI) effective and adjusted versus precipitation of the Ipojuca river

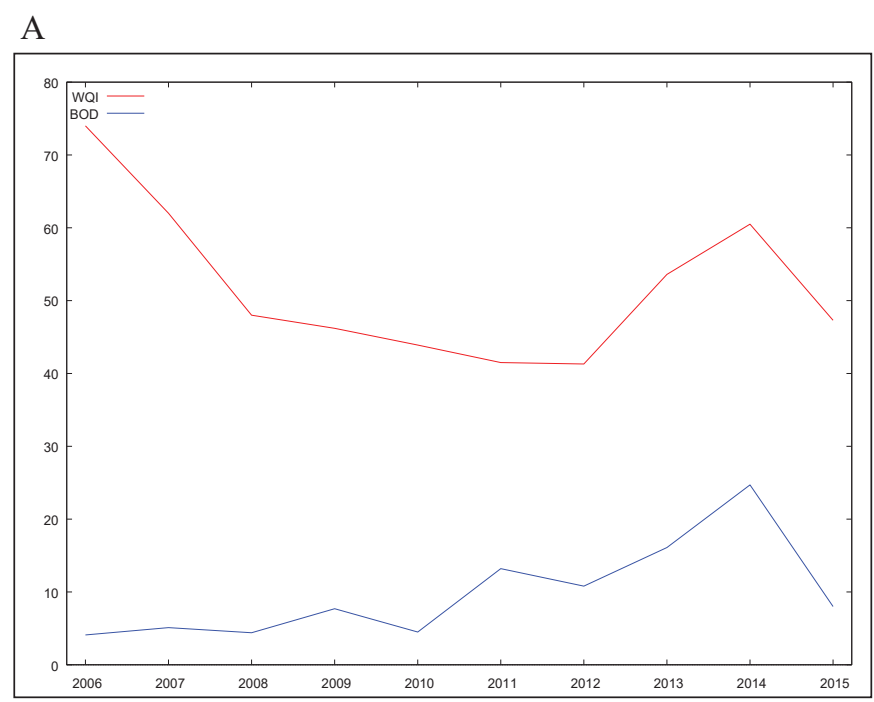

B

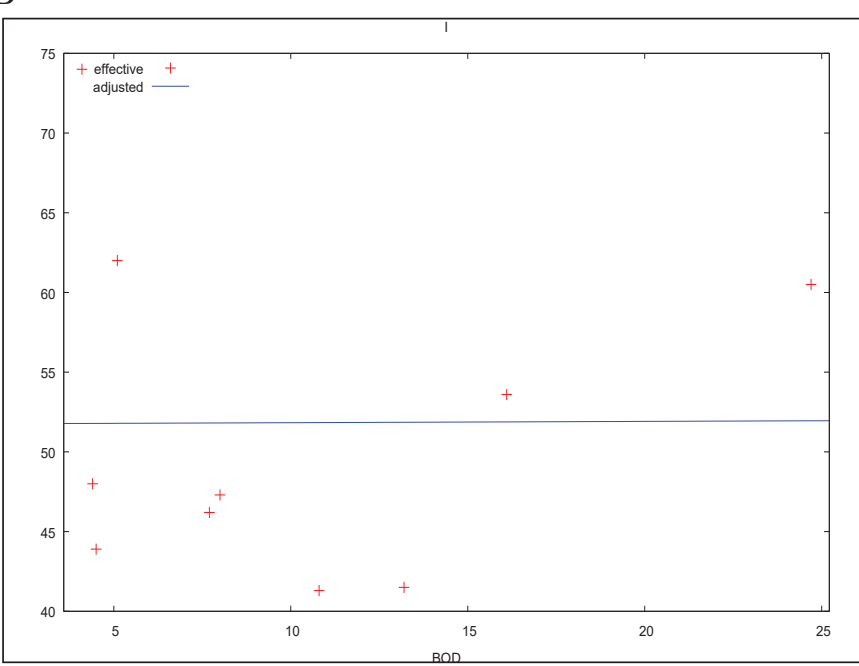

C

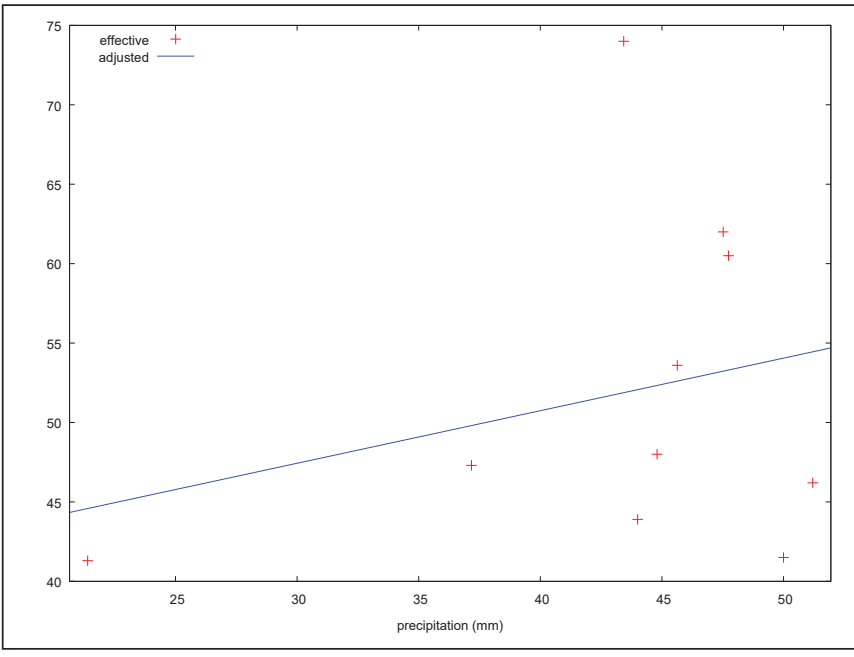


The BOD in the waters of the Ipojuca river has little influence on the water quality index, according to the regression equation, increasing by one unit the BOD there is an increment of only 0.0081 , but it is observed that in the BOD peaks there are decreases of WQI. Thus, it is verified that there is influence of the BOD in the WQI, being one of the fundamental parameters to be analyzed, Figure 4A.

In Figure 4B, we see that there is a stability, without reduction or significant increase in the WQI and BOD, after the adjustments with the regression equation obtained $(\mathrm{WQI}=51.75+0.0081 * \mathrm{BOD})$. When evaluating WQI with precipitation the same period recorded, according to the regression equation (WQI= 37.51+0.331*BOD), it is verified that $1 \mathrm{~mm}$ adds about 0.331 in the WQI (Figure 4C). It is noticed that the increase in precipitation helps to increase the index of water quality, resulting in water with better quality.

In studies conducted by SAE (2003) found that the use of water in the basin of Ipojuca are $49.1 \%$ for animal consumption, $20.8 \% 6.6 \%$ intended for human consumption and for irrigation. Sobral et al. (2015) evaluating the quality of the water in the river Ipojuca detected heterogeneous behavior and claim that the high rates may be related to periods of drought in the region.

Notice that in Figure 2, 3 and 4 the data is oscillatory, with high and low depending on the year analyzed, it is remarkable that in the wettest years for greater dilution of sewage released and so lower BOD, but in times of droughts and higher concentration of sewers for BOD elevation, reducing water quality. However, this factor must be taken into consideration but it is not crucial, that is responsible for the heterogeneity of the BOD. However, in times of droughts and higher concentration of sewers for BOD elevation, reducing water quality.

However, this factor must be taken into consideration but it is not crucial, that is responsible for the heterogeneity of the BOD. Depends on communities and nearby industries and levels of raw sewage released to water bodies of the watershed. It is important that it is done the sanitation of towns and that the sewage is treated to launch appropriate conditions causing minimal environmental impacts, in addition to conserving water quality for the community and its various uses.

\section{Conclusion}

The Water Quality Indices of the studied hydrographic basins were classified as good in most of the studied years.

The quality of the waters of the watershed of the river Capibaribe has over the time analyzed better conditions, while the river Ipojuca and Igarassu had high levels of BOD, with lower water quality.

\section{Reference}

ARAÚJO, A. M. Qualidade das águas estuarinas em Recife (1995/1996). Ciência e Engenharia, Uberlândia, v. 9, n. 1, p. 32-39, 2000.

BIONE, M.A.A.; DANTAS, R.M.L.; TAVARES, R.G.; ALBUQUERQUE, C.G.; SOARES, T.M.; SILVA, E.F.F. Poluição do Rio Capibaribe por esgoto doméstico. IN: IX Jornada de Ensino, Pesquisa e Extensão, 2009.

FIDEM. Proteção das áreas estuarina. Recife, 1987. 22 p.

FIGUEIRÊDO, A. C. Avaliação e diagnóstico da qualidade da água do açude de apipucos, Recife-PE. 2008.104 f. Dissertação (Mestrado em Engenharia Agrícola) - Universidade Federal Rural de Pernambuco, Recife, 2008.

FRANCO, R. A. M.; HERNANDEZ, F. B. T. Qualidade da água para irrigação na microbacia do Coqueiro, Estado de São Paulo. Revista Brasileira de Engenharia Ambiental, v. 13, n. 6, p. 772-780, 2009.

IBAMA. Aspectos gerais da hidrobiologia do Litoral Norte de Pernambuco - Brasil / Renaldo Tenório de Moura, organizador. 2009.138p

MELO NETO, J. de O.; LISBOA, J. P. N.; SANTANA, L. L.; SANTOS, C. Z. A.; SANTANA, C. L.; CHAGAS, R. M. et al. Aplicação de técnicas de geoprocessamento na análise da supressão da cobertura vegetal no baixo curso do rio Poxim. In: SIMPÓSIO REGIONAL DE GEOPROCESSAMENTO E SENSORIAMENTO REMOTO, 4., 2008, Aracaju. Anais... Aracaju: Embrapa Tabuleiros Costeiros, 2008.

Ministério do Meio Ambiente. Resolução CONAMA 357/05. Disponível em <http://www.crq4.org.br/downloads/ resolucao357.pdf> Acesso em 16 Dezembro 2017. 
PERNAMBUCO. Atlas de Bacias Hidrográficas de Pernambuco. SECTMA. Coord. Silva, S.R. Recife, 2006, 104p.

PERNAMBUCO. Rio Ipojuca: Série Bacias Hidrográficas de Pernambuco. Agência Condepe/Fidem. Recife, 2005. $64 \mathrm{p}$.

ROCHA, J. L. S.; REGO, N. A. C.; SANTOS, J. W. B.; OLIVEIRA, R. M.; MENEZES, M. Indicador integrado de qualidade ambiental aplicado à gestão de bacia hidrográfica do rio Juquiriçá, BA, Brasil. Revista Ambiente \& Água, v. 5, n. 1, p. 89-101, 2010.

SILVA, A. DE S.; BUSCHINELLI, C. C. de A.; RODRIGUES, I. A.; MACHADO R. E. Índice de sustentabilidade ambiental do uso da água (ISA_ÁGUA): municípios da região do entorno do rio Poxim, SE. Jaguariúna: Embrapa Meio Ambiente, 2004. 46 p.

SILVA, B. A. W.; AZEVEDO, M. M.; MATOS, J. S. Gestão ambiental de bacias hidrográficas urbanas. Revista VeraCidade, v. 3, n. 5, p. 1-7, 2006.

SILVA, L. M.; SOUZA, E. H.; ARREBOLA, T. M.; JESUS, T. A. Ocorrência de um surto de hepatite A em três bairros do município de Vitória (ES) e sua relação com a qualidade da água de consumo humano. Ciência \& Saúde Coletiva, v. 14, n. 6, p. 2163-2167, 2009.

SOBRAL, M. C.; GUNKEL, G.; ROHN, H.; AURELIANO, J. Avaliação do monitoramento da qualidade da água de rios intermitentes: o caso do rio Ipojuca, Pernambuco. Available from: https://www.researchgate.net/ publication/237814980_AVALIACAO_DO_MONITORAMENTO_DA_QUALIDADE_DA_AGUA_DE_RIOS_ INTERMITENTES_o_caso_do_rio_Ipojuca_Pernambuco [accessed Dec 27 2017].

State Agency of Environment - SAE. Mapeamento dos usos da água e delimitação das zonas homogêneas. Programa nacional do Meio Ambiente II. 2003. 29 p.

Sustainable Development indicators- (SDI). Available in: https://sidra.ibge.gov.br/pesquisa/ids/documentos .2017.

TEIXEIRA, S. F.; CAMPOS, S.S.; ANDRADE, A.L.R.H. Qualidade da água no baixo rio Capibaribe, Recife, Pernambuco. In: Encontro das águas, UNICAP, Recife, 2013. 


\section{Viviane Farias Silva}

Universidade Federal de Campina Grande, PB, Brasil

E-mail: flordeformosur@hotmail.com

Participação do autor:

\section{Dihego Souza Pessoa}

Universidade Federal de Campina Grande, PB, Brasil

E-mail: dihegosouza@hotmail.com

Participação do autor:

\section{Thalis Leandro Bezerra Lima}

Universidade Federal de Campina Grande, PB, Brasil

E-mail: thalisleonardo@gmail.com

Participação do autor:

\section{Ana Maria Ferreira Cosme}

Universidade Federal de Campina Grande, PB, Brasil

E-mail: anacosme@hotmail.com

\section{Participação do autor:}

\section{Vera Lucia Antunes Lima}

Universidade Federal de Campina Grande, PB, Brasil

E-mail: antunes@deag.ufcg.edu.br

\section{Participação do autor:}

